\title{
Evaluation of two underwater biopsy probes for in situ collection of shark tissue samples
}

\author{
William D. Robbins \\ School of Marine Biology and Aquaculture, James Cook University, Townsville, Queensland 4811, Australia
}

\begin{abstract}
The design and practicality of underwater biopsy probes was investigated for the in situ collection of shark tissue for molecular analysis. Two probe designs were tested, differing in the structure of their penetrating barrel. The first probe design (Type I) had rearward-facing teeth cut into the barrel, while the second design (Type II) used dental broaches to retain the tissue. Both probe designs successfully retained an average of over $50 \mathrm{mg}$ of skin and muscle tissue, with Type II probes showing a greater consistency in the weight of tissue retained. Type II probes took longer to prepare before each use; however, they are favored for low-abundant species where a higher retention rate of tissues is important. Both types of probe were easily disassembled underwater, allowing the barrel of tissue to be placed into preservative immediately. Underwater biopsy probing is advantageous as it reduces stress and injury to individuals that can be approached by divers. It also removes the difficulties of animal procurement and restraint. For marine species that are difficult to capture or have low population numbers, tissue collection by biopsy probe is a highly desirable method of obtaining samples.
\end{abstract}

KEY WORDS: Biopsy probe - Underwater tissue collection · Molecular $\cdot$ Shark $\cdot$ Carcharhinidae

\section{INTRODUCTION}

Investigation of a population's genetic structure requires the collection of tissue samples from individuals for DNA analysis. To date, the majority of shark and ray genetic analyses have been undertaken on visceral or muscle tissue (Heist et al. 1996, Delarbre et al. 1998, Sandoval-Castillo et al. 2004). This has invariably involved the sacrifice of the study animals, either through commercial sources or research collections. Non-lethal collections of genetic material (such as fin clippings) are uncommon and usually only carried out in conjunction with tag and release studies (Feldheim et al. 2001). Unfortunately, even tag and release techniques require the capture and surfacing of individuals, usually through netting or line fishing. This can result in stress and injury to the animal, or even death (Hoffmayer \& Parsons 2001, Sundström \& Gruber 2002). Net and line fishing techniques also result in the capture of incidental or by-catch species (Francis et al. 2001, Notarbartolo-di-Sciara et al. 2003).
Many exploited shark populations are currently in decline (Campana et al. 2002, Baum et al. 2003) or low in abundance (Graham et al. 2001, Baum \& Myers 2004). Shark species often have limited resilience to exploitation due to their life history traits of late age at maturity and low fecundities (Holden 1974). Especially at risk are medium to large coastal sharks (Smith et al. 1998, Frisk et al. 2001). In situations involving rare or declining populations, it is important to streamline the techniques for successful data collection while minimizing the impact on sampled individuals.

Non-lethal tissue collections are commonly taken from wild cetaceans. These involve the firing of stainless steel darts to retain a plug of skin and blubber (Aguilar \& Nadal 1984, Barrett-Lennard et al. 1996). Researchers approach the target animal on boats, firing the darts with crossbows (Hooker et al. 2001), above-water spearguns (Borrell et al. 2004) or modified rifles (Krützen et al. 2002). Equivalent underwater techniques do not appear to have been developed. For shark species found in shallow waters, underwater col- 
lection of tissue samples allows divers to select specific animals to sample without the need for capture or restraint. This study evaluated the design and practicality of 2 types of underwater biopsy probe to collect skin and muscle tissue samples from reef sharks for molecular analysis.

\section{MATERIALS AND METHODS}

Two types of biopsy probe were machined from mild stainless steel, differing only in the structure of the penetrating barrel. In the first probe, a series of three $4 \mathrm{~mm}$ rearward-facing notches were cut into the barrel to retain tissue (Fig. 1A-C). In the second probe, 2 Kerr $21 \mathrm{~mm}$ ISO4 barbed broaches (dental probes) were twisted together and positioned inside the barrel of the probe (Fig. 1D-E). The dental broaches had
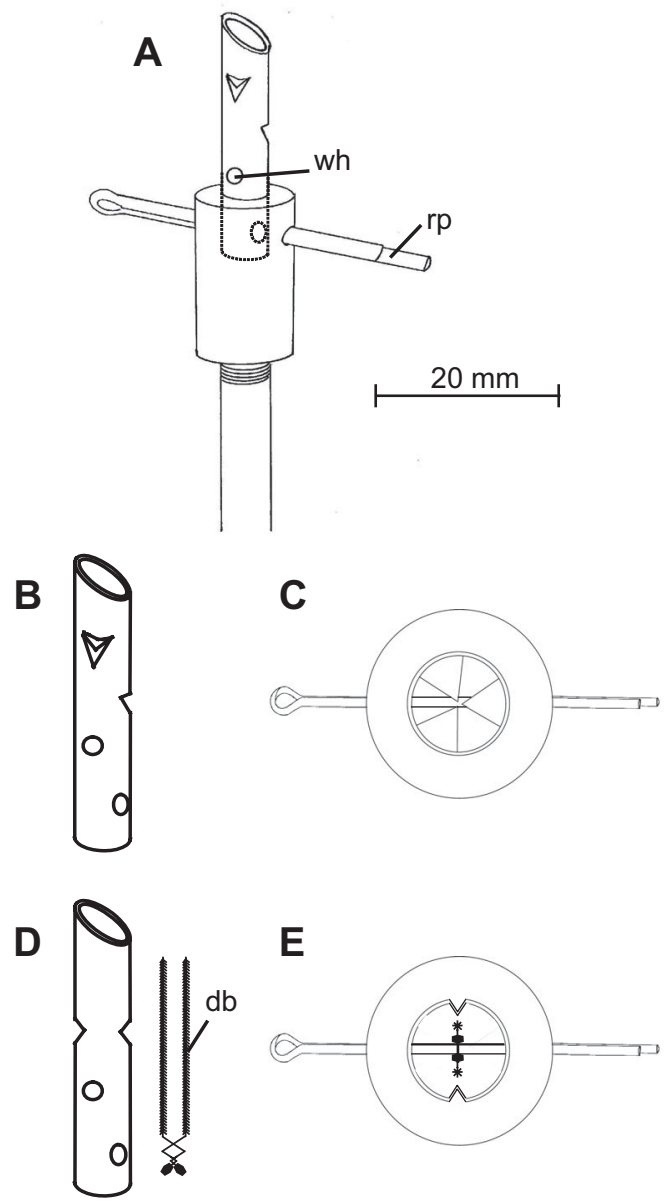

Fig. 1 (A) Complete biopsy probe with Type I barrel insert. Dashed lines indicate extent of barrel inside the probe. $(B, C)$ lateral and aerial views of Type I barrel insert and (D, E) Type II barrel insert. wh: water effusion hole; rp: barrel retaining pin; db: dental broaches used with Type II barrel. Scale bar applicable to (A) only rearward-facing serrated barbs running along their length and were held in place by the barrel-retaining pin (Fig. 1A). Two indents were made halfway down the barrel of the second probe to constrict the bore of the barrel. Both types of barrel had a small $(2.4 \mathrm{~mm})$ hole at their base to allow effusion of water from the barrel as it pushed into the shark. Biopsy probes were screwed to the end of an $1100 \mathrm{~mm}$ spear and fired from a medium-pressured Mares Cyrano 1100 pneumatic speargun.

Three species of reef shark (Family Carcharhinidae) were sampled at the Cocos (Keeling) southern atoll $\left(12^{\circ} 08^{\prime} \mathrm{S}, 9^{\circ} 52^{\prime} \mathrm{E}\right)$ and Marquesas Island group $\left(08^{\circ} 56^{\prime} \mathrm{S}, 140^{\circ} 07^{\prime} \mathrm{W}\right)$. Sharks were targeted at an angle ca. $20^{\circ}$ from perpendicular, with biopsy probes shot into the dorsal musculature below the first dorsal fin. Distance to sharks sampled ranged between 2 and $5 \mathrm{~m}$. After use, probe barrel assemblies were soaked in a $42 \mathrm{~g} \mathrm{l}^{-1}$ solution of sodium hypochlorite (household bleach) for $30 \mathrm{~min}$ to remove any remaining traces of tissue before rinsing in fresh water.

Probed tissue wet wt was measured to 5 decimal places using a Mettler AE240 electronic balance. DNA was subsequently extracted from the tissues based on the protocols of Sunnucks \& Hales (1996). The standard weight of tissue used per DNA extraction was $3 \mathrm{mg}$. All biopsy probe samples retaining at least $3 \mathrm{mg}$ of tissue were therefore considered successful.

\section{RESULTS}

Tissue samples were obtained from the whitetip reef shark Triaenodon obesus, the grey reef whaler Carcharhinus amblyrhynchos, and the blacktip reef shark C. melanopterus. All sharks sampled were between 1.1 and $1.4 \mathrm{~m}$ total length and weighed ca. 10 to $12 \mathrm{~kg}$. Biopsy samples obtained usually consisted of a circular patch of skin, with muscle tissue attached. Probes penetrated no further than the retaining pin (ca. $25 \mathrm{~mm}$ ), leaving a $5 \mathrm{~mm}$ diameter external lesion in the shark.

Tissues from the 3 species were pooled for analyses. Both probe types retained on average over $50 \mathrm{mg}$ of tissue per use (Fig. 2). The mean tissue retention rate did not differ significantly between the 2 probe types ( $t$-test; $t=0.08, \mathrm{p}>0.05)$. Type I probes had a greater variance; however, the standard errors of each probe type were similar due to the greater sample size of Type I probe data. The weight of tissue removed from each shark was ca. $0.0005 \%$ of body weight.

Three milligrams was the standard weight of tissue used in DNA extractions. This weight was therefore considered the benchmark for a 'successful' tissue collection. Although both probe types tested retained tissue, Type II probes retained a higher proportion of 


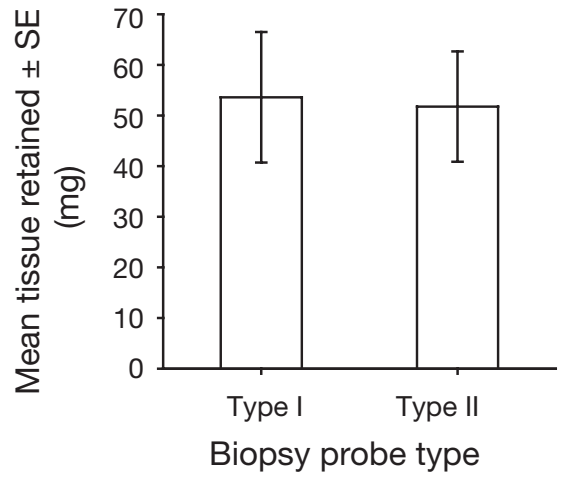

Fig. 2. Mean wet weight of tissue retained from reef sharks using Type I and Type II biopsy probes

analyzable tissue than Type I probes (Table 1). The dental broaches were efficient at holding the tissue, while the indents in the barrel compressed the tissue slightly, allowing the broaches a better grip. However, the increased efficiency of Type II probes was balanced by the longer preparation time required before each use. The dental broaches required individual alignment with tweezers prior to each use. This alignment took up to 5 min per probe. Probe Type I required no such preparation.

\section{DISCUSSION}

The use of underwater biopsy probes allowed the collection of shark tissue for molecular analysis, without the capture or restraint of individuals. Once the diver was within spearing range of the shark, both probe types offered a rapid and simple technique for taking skin and muscle tissue samples from selected individuals. Both types of probe were easy to disassemble underwater and allowed immediate preservation of tissues. Although the mean wet wt of tissue collected was similar for both probes, Type II probes were found to deliver the most consistent results. In situations where rare species are under investigation, it is important to maximize the success rate of sampling. As such, it is worth the additional preparation time required for Type II probes to obtain a higher proportion of successful tissue retentions. The benefit of
Type I probes lies in their minimal preparation time. When the number of target individuals is not a limitation, the ease of preparation of Type I probes may outweigh the lower successful tissue retention rates. With advances in molecular extraction protocols, DNA can now be successfully extracted from tissue quantities as small as $1 \mathrm{mg}$ (Kasajima et al. 2004). If protocols such as this can be used on shark tissues, the successful retention rate of Type I probes will improve.

Female sharks are often seen with significantly greater injury from mating, caused by the male grasping the female with his teeth during copulation (Whitney et al. 2004). Female sharks and rays compensate for this mating behavior by having dermal layers up to $50 \%$ thicker than males (Kajiura et al. 2000). Male and female Triaenodon obesus are also often sighted with dermal abrasions incurred through foraging through the reef matrix (W. Robbins field obs.). Differences in dermal thickness presented no problem for the biopsy probes as the protocol used extracted DNA from both muscle and skin samples. Probed individuals of both sexes were sighted up to $5 \mathrm{~d}$ after sampling, with no obvious distress or adverse behavior.

Underwater tissue sampling has a number of practical advantages. It allows the user to actively select the target animals, as opposed to non-selective techniques (e.g. line-fishing), which may also result in the catch of non-target individuals or species. Species vary in their predisposition to attractants such as baited hooks, both in terms of catch rates and catchability (Compagno 1984, Berkeley \& Campos 1988). Hence the ability to target only the animals required increases costefficiency through reduced sampling time. Stress and injury risk in target animals are reduced, as capturing and surfacing with nets or lines is avoided. Fibronecrosis, luminal obstructions and bacterial infections associated with individuals ingesting and retaining hooks are also avoided (Borucinska et al. 2002). It should be noted, however, that the lack of removal of individuals, together with the minimal scarring from the biopsy probes, requires the user to take caution so that they do not accidentally resample the same individuals.

While this study focused on coral reef carcharhinids, underwater biopsy probes are likely to be successful with other benthic or coastal sharks. Orectolobids (wobbegongs), ginglymostomatids (nurse sharks),

Table 1. Variation in the wet weight of tissue collected and percent retention with 2 types of biopsy probe

\begin{tabular}{|lccccc|}
\hline Probe type & $\begin{array}{c}\text { Minimum tissue } \\
\text { retained }(\mathrm{mg})\end{array}$ & $\begin{array}{c}\text { Maximum tissue } \\
\text { retained }(\mathrm{mg})\end{array}$ & $\begin{array}{c}\text { \% Tissue } \\
\text { retention }\end{array}$ & $\begin{array}{c}\text { \% Successful } \\
\text { retention }(>3 \mathrm{mg})\end{array}$ & Number of trials \\
\hline Type I & 0.5 & 384 & 87 & 70 & 37 \\
Type II & 6.6 & 122 & 91 & 91 & 11 \\
\hline
\end{tabular}


other carcharhinids (such as Negaprion sp.) and heterodontids (horn sharks) are all possible candidates for sampling with this technique. Although not trialed, rare or endangered species of ray such as Mobulidae (devilrays) may also be sampled with biopsy probes. These animals are often found in shallow coral reef waters and are approachable by divers. Biting of the female also occurs in this species during mating (Yano et al. 1999); hence these females would be familiar with dermal abrasions.

Probe tissue collection is also suitable for larger teleostean fishes. Low-density or patchily distributed species such as Cheilinus undulatus and Bolbometapon muricatum are both thought to be highly vulnerable to fishing pressure (Sadovy et al. 2003, Donaldson \& Dulvy 2004). This technique offers a non-lethal alternative when only genetic samples are required. Opportunistic sampling showed that the probes also retain the large scales of both species, providing a greater amount of tissue available for molecular analysis. Obtaining tissue samples through minimally invasive sampling techniques benefits both the study species and the researcher. When the sacrifice of animals is not necessary, these benefits make the use of biopsy probes highly desirable.

Acknowledgements. I thank National Geographic for funding given to J. H. Choat for research at Cocos (Keeling) atoll. R. Gegg assisted with the manufacture of the probes, while J. Schultz provided molecular advice and dental broaches. Thank you to A. P. Kerswell, J. H. Choat and 3 anonymous reviewers for their valuable contributions to the manuscript. This project was undertaken with James Cook University animal ethics approval.

\section{LITERATURE CITED}

Aguilar A, Nadal J (1984) Obtención de biopsias hipodérmicas de cetáceos en libertad. Inv Pesq 48:23-29

Barrett-Lennard LG, Smith TG, Ellis GM (1996) A cetacean biopsy system using lightweight pneumatic darts, and its effect on the behavior of killer whales. Mar Mammal Sci 12:14-27

Baum JK, Myers RA (2004) Shifting baselines and the decline of pelagic sharks in the Gulf of Mexico. Ecol Lett 7: 135-145

Baum JK, Myers RA, Kehler DG, Worm B, Harley SJ, Doherty PA (2003) Collapse and conservation of shark populations in the Northwest Atlantic. Science 299:389-392

Berkeley SA, Campos WL (1988) Relative abundance and fishery potential of pelagic sharks along Florida's east coast. Mar Fish Rev 50:9-16

Borrell A, Cantos G, Pastor T, Aguilar A (2004) Levels of organochlorine compounds in spotted dolphins from the Coiba archipelago, Panama. Chemosphere 54:669-677

Borucinska J, Kohler N, Natanson L, Skomal G (2002) Pathology associated with retained fishing hooks in blue sharks, Prionace glauca (L.), with implications for their conservation. J Fish Dis 25:515-521
Campana SE, Joyce W, Marks L, Natanson LJ and 9 others (2002) Population dynamics of the porbeagle in the northwest Atlantic Ocean. North Am J Fish Manage 22: 106-121

Compagno LJV (1984) FAO species catalogue, Sharks of the world. An annotated and illustrated catalogue of shark species known to date. Part 2: Carcharhiniformes. FAO Fisheries Synopsis 4(2):251-655

Delarbre C, Spruyt N, Delmarre C, Gallut C, Barriel V, Janvier P, Laudet V, Gachelin G (1998) The complete nucleotide sequence of the mitochondrial DNA of the dogfish, Scyliorhinus canicula. Genetics 150:331-344

Donaldson TJ, Dulvy NK (2004) Threatened fishes of the world: Bolbometopon muricatum (Valenciennes 1840) (Scaridae). Environ Biol Fish 70:373-373

Feldheim KA, Gruber SH, Ashley MV (2001) Population genetic structure of the lemon shark (Negaprion brevirostris) in the western Atlantic: DNA microsatellite variation. Mol Ecol 10:295-303

Francis MP, Griggs LH, Baird SJ (2001) Pelagic shark bycatch in the New Zealand tuna longline fishery. Mar Freshw Res 52:165-178

Frisk MG, Millar TJ, Fogarty MJ (2001) Estimation and analysis of biological parameters in elasmobranch fishes: a comparative life history study. Can J Fish Aquat Sci 58: 969-981

Graham KJ, Andrew NL, Hodgson KE (2001) Changes in relative abundance of sharks and rays on Australian South East Fishery trawl grounds after twenty years of fishing. Mar Freshw Res 52:549-561

Heist EJ, Musick JA, Graves JE (1996) Genetic population structure of the shortfin Mako (Isurus oxyrinchus) inferred from restriction fragment length polymorphism analysis of mitochondrial DNA. Can J Fish Aquat Sci 53:583-588

Hoffmayer ER, Parsons GR (2001) The physiological response to capture and handling stress in the Atlantic sharpnose shark, Rhizoprionodon terraenovae. Fish Physiol Biochem 25:277-285

Holden MJ (1974) Problems in the rational exploitation of elasmobranch populations and some suggested solutions. In: Harden FR (ed) Sea fisheries research. Paul Elek, London, p 117-137

Hooker SK, Iverson SJ, Ostrom P, Smith SC (2001) Diet of northern bottlenose whales inferred from fatty-acid and stable-isotope analyses of biopsy samples. Can J Zool 79: 1442-1454

Kajiura SM, Sebastian AP, Tricas TC (2000) Dermal bite wounds as indicators of reproductive seasonality and behaviour in the Atlantic stingray, Dasyatis sabina. Environ Biol Fish 58:23-31

Kasajima I, Ide Y, Ohkama-Ohtsu N, Hayashi H, Yoneyama T, Fujiwara T (2004) A protocol for rapid DNA extraction from Arabidopsis thaliana for PCR analysis. Plant Mol Biol Reporter 22:49-52

Krützen M, Barré LM, Möller LM, Heithaus MR, Simms C, Sherwin WB (2002) Biopsy system for small cetaceans: darting success and wound healing in Tursiops spp. Mar Mammal Sci 18:863-878

Notarbartolo-di-Sciara G, Zanardelli M, Jahoda M, Panigada S, Airoldi S (2003) The fin whale Balaenoptera physalus (L. 1758) in the Mediterranean Sea. Mammal Rev 33: 105-150

Sadovy Y, Kulbicki M, Labrosse P, Letourneur Y, Lokani P, Donaldson TJ (2003) The humphead wrasse, Cheilinus undulatus: synopsis of a threatened and poorly known giant coral reef fish. Rev Fish Biol Fish 13:327-364 
Sandoval-Castillo J, Rocha-Olivares A, Villavicencio-Garayzar C, Balart E (2004) Cryptic isolation of Gulf of California shovelnose guitarfish evidenced by mitochondrial DNA. Mar Biol 145:983-988

Smith SE, Au DW, Show C (1998) Intrinsic rebound potentials of 26 species of Pacific sharks. Mar Freshw Res 49: 663-678

Sundström LF, Gruber SH (2002) Effects of capture and transmitter attachments on the swimming speed of large juvenile lemon sharks in the wild. J Fish Biol 61:834-838

Editorial responsibility: Otto Kinne (Editor-in-Chief), Oldendorf/Luhe, Germany
Sunnucks P, Hales DF (1996) Numerous transposed sequences of mitochondrial cytochrome oxidase I-II in aphids of the genus Sitobion (Hemiptera: Aphididae). Mol Biol Evol 13:510-524

Whitney NM, Pratt HL, Carrier JC (2004) Group courtship, mating behaviour and siphon sac function in the whitetip reef shark, Triaenodon obesus. Anim Behav 68:1435-1442

Yano K, Sato F, Takahashi T (1999) Observations of mating behavior of the manta ray, Manta birostris, at the Ogasawara Islands, Japan. Ichthyol Res 46:289-296

Submitted: July 5, 2005; Accepted: September 19, 2005 Proofs received from author(s): March 7, 2006 